\title{
Twenty-seven-nucleotide repeat insertion in the rp/V gene confers specific resistance to macrolide antibiotics in Staphylococcus aureus
}

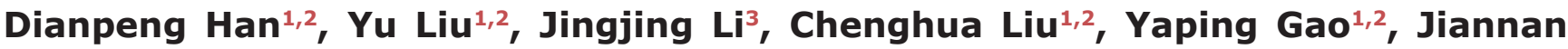 \\ Feng $^{1,2}$, Huizhe Lu ${ }^{4}$ and Guang Yang ${ }^{1,2}$ \\ ${ }^{1}$ Beijing Institute of Basic Medical Sciences, Beijing, China \\ ${ }^{2}$ State Key Laboratory of Toxicology and Medical Countermeasures, Beijing, China \\ ${ }^{3}$ Henan University School of Basic Medical Science, Kaifeng, China \\ ${ }^{4}$ Department of Applied Chemistry, College of Science, China Agricultural University, Beijing, China \\ Correspondence to: Huizhe Lu, email: Iuhz@cau.edu.cn \\ Guang Yang, email: yangg62033@outlook.com
}

Keywords: macrolides resistant; rp/V; repeat insertion; Staphylococcus aureus

Received: February 09, $2018 \quad$ Accepted: April 28, $2018 \quad$ Published: May 25, 2018

Copyright: Han et al. This is an open-access article distributed under the terms of the Creative Commons Attribution License 3.0 (CC BY 3.0), which permits unrestricted use, distribution, and reproduction in any medium, provided the original author and source are credited.

\section{ABSTRACT}

Macrolide antibiotics are used for treatment of soft-tissue infection caused by Staphylococcus aureus in humans. However, infections with S. aureus are increasingly difficult to treat owing to the emergence and rapid spread of multiple-drug resistant $S$. aureus. Resistance to macrolide in $S$. aureus is mostly due to the modification of 23 S rRNA by methylases encoded by erm genes. Here, we have identified that a 27-nucleotide repeat sequence insertion in the $r p / V$ gene induced a specific resistance to macrolide antibiotics. An erythromycin-resistant strain, $8325^{\mathrm{ER}+}$, was screened by resistance to erythromycin from the macrolide-sensitive strain $8325-4$. Comparative genome sequencing analysis showed that $8325^{\mathrm{ER}+}$ contained a $27-n t$ repeat sequence insertion in the rp/V gene that encodes the ribosomal protein L22, when compared to its parent strain. The 27-nt repeat sequence led to an insertion of 9 amino acids in L22, which had been identified to reduce the sensitivity to erythromycin and other macrolide antibiotics. Moreover, we show that the ectopic expression of the mutated $r p / V$ gene containing the $27-n t$ repeat sequence insertion in several susceptible strains specifically conferred resistance to macrolide antibiotics. Our findings present a potential mechanism of resistance to macrolide antibiotics in $S$. aureus.

\section{INTRODUCTION}

Staphylococcus aureus is the leading Gram-positive bacterium that can cause infections in humans worldwide, including mild skin infections, bacteremia, sepsis, and endocarditis [1-3]. Over the last century, infections with $S$. aureus have become increasingly difficult to treat owing to the emergence and rapid spread of multiple-drug resistant $S$. aureus [4-6].

Macrolides, which consist of a 14- to 16-membered lactone ring with different appended sugars and comprise a key group of inhibitors of bacterial translation, are ribosome-targeting antibiotics used to treat infections caused by Staphylococcus species [7, 8]. Erythromycin, azithromycin, and clarithromycin are members of the macrolide antibiotics, a large group of antibacterial agents that include natural or newer semi-synthetic compounds $[9,10]$. Their inhibitory activity depends on binding to a site near the ribosomal nascent peptide exit tunnel, which starts at the peptidyl transferase center and spans the body of the large ribosomal subunit, thereby halting translation of a particular subset of nascent peptides [11-13].

Resistance to macrolide may be mediated by three primary mechanisms: a) modification of ribosomes, 
such as dimethylation of a unique adenine residue in the $23 \mathrm{~S}$ ribosomal RNA (rRNA), A2085 in S. aureus (corresponding to E. coli A2058), which is located in the macrolide-binding site in the nascent peptide exit tunnel, by the erythromycin resistance methyltransferase encoded by the erm genes [14-16]; b) activated efflux systems, involving a member of the ATP-binding cassette $(\mathrm{ABC})$ family of transporters encoded by the macrolide-streptogramins resistance A $(m s r A)$ gene, keeping intracellular antibiotic concentration at a subtoxic level and conferring inducible resistance to erythromycin and type B streptogramins in staphylococci [17, 18]; and c) production of antibioticinactivating enzymes, such as phosphorylase, a macrolide phosphotransferase $C$ (encoded by $m p h C$ in staphylococci) that inactivates antibiotics $[19,20]$. According to other studies, mutations in Escherichia coli rplV and rplD genes coding for ribosomal proteins L22 and L4, respectively, can also confer resistance to macrolide antibiotics [21, 22]. A mutant change in rplV was also observed in antibiotic-resistant $S$. aureus [23].

Here, we screened a resistant strain obtained by culturing the sensitive $S$. aureus strain 8325-4 in the presence of erythromycin. A 27-nt repeat sequence insertion in the rplV ( $\left.r p l V^{\text {tndel }}\right)$ gene was identified in this erythromycin-resistant strain, which induced specific resistance to macrolides.

\section{RESULTS}

\section{An erythromycin-resistant strain of $S$. aureus 8325-4 is screened in vitro}

To explore the mechanism underlying the resistance to macrolide in $S$. aureus, we cultured wildtype $S$. aureus 8325-4 in BHI medium while continuously doubling the concentration of erythromycin (Figure 1A). An isolate with acquired resistance to erythromycin was screened and named $8325^{\mathrm{ER}+}$. It was able to grow in a medium containing $80 \mu \mathrm{g} / \mathrm{mL}$ of erythromycin, and the survival rates of $8325^{\mathrm{ER}+}$ strain in different concentration of erythromycin were significantly higher than the parent strain (Figure 1B). Besides, the minimal inhibitory concentration (MIC) of erythromycin of $8325^{\mathrm{ER}+}$ was 160 $\mu \mathrm{g} / \mathrm{mL}$ in a drug susceptibility test, which was interpreted as erythromycin resistant according to Clinical and Laboratory Standards Institute (CLSI) criteria [24].

In the further investigation, $8325^{\mathrm{ER}+}$ was cultured in BHI broth without erythromycin for 20 generations, the susceptibility to erythromycin of bacteria from different generations was determined individually. We found that the MIC of S. aureus from different generations was not altered, which suggested that resistance to erythromycin in $8325^{\mathrm{ER}+}$ was inheritable.

\section{Whole-genome sequencing identifies gene mutations in $\mathbf{8 3 2 5}^{\mathrm{ER}+}$}

To test whether high expression of known erythromycin resistance genes in $8325^{\mathrm{ER}+}$ contributed to the resistance to erythromycin, we extracted total RNA from the erythromycin-sensitive strain 8325-4 and the erythromycin-resistant strain $8325^{\mathrm{ER}+}$ (Supplementary Figure 1A). Reverse transcription-polymerase chain reaction (RT-PCR) showed that erythromycin resistancerelated genes, including $23 \mathrm{~S}$ rRNA adenine-specific $N$-methyltransferases (encoded by ermA/ermB/ erm $C$ ), mphC, and $m s r A$ were not detected in $8325^{\mathrm{ER}+}$ (Supplementary Figure 1B). These results suggest that another mechanism is responsible for the resistance to erythromycin of $8325^{\mathrm{ER}+}$.

To investigate the potential genes involved in the resistance occurrence to erythromycin, we extracted total genomic DNA and compared the genome sequence of $8325^{\mathrm{ER}+}$ with that of $8325-4$.

Sequence analysis showed that ten genes mutated, and six of them encoded different proteins (Table 1). Considering that five of the ten mutated genes were involved in the translation process, we decided to compare cell growth between $8325^{\mathrm{ER}+}$ and $8325-4$. We did not see a significant difference between both strains (Supplementary Figure 1C).

Further analysis showed that seven genes were identified with one or two nucleotide mutations, and only one gene, $r p l V$, encoding ribosomal protein L22 exhibited an insertion of a 27-nt fragment (Table 1). In further investigation, we found that sequence of the insertion segment correspond to a duplication of the region 292-318 of $r p l V$ (Figure 2A). Moreover, the insertion of the 27-nt fragment happen at nucleotide $292 \mathrm{C}$ or $318 \mathrm{C}$ in $r p l V$ gene in $8325^{\mathrm{ER}+}$ (Figure 2B). Furthermore, we found that the 27-nt fragment led to a 9-amino acids insertion but did not induce a frame-shifting mutation (Figure 2C).

\section{Twenty-seven-nucleotide insertion in the rplV $\left(r p l V^{\text {indel }}\right)$ gene induces resistance to erythromycin in $S$. aureus}

The rplV gene encodes the ribosomal 50S subunit protein L22, which is important for ribosomal 50S subunit assembly at the early stage. It is essential for the formation of the nascent peptide exit tunnel of the mature ribosome [22]. Given that mutation in the rplV gene was reported to be involved in resistance to antibiotics in E. coli and $S$. aureus [11, 21-23], we focused on investigating whether the $r p l V^{\text {indel }}$ gene induced resistance to erythromycin. Firstly, the rplV genes were amplified by PCR from the genomes of $8325^{\mathrm{ER}+}$ and $8325-4$. We found the band of PCR product from $8325^{\mathrm{ER}+}$ was bigger than that from 8325-4 (Figure 3A). Following analysis showed that the sequence of $r p l V$ gene in $8325^{\mathrm{ER}+}$ containing the $27-\mathrm{nt}$ 
insertion fragment, which was consistent with the genome sequence results (Figure 3B).

To evaluate the role of $r p l V^{\text {tndel }}$ in raising resistance of $S$. aureus to erythromycin, we generated several erythromycin-susceptible $S$. aureus strains $\left(8325-4^{\text {indel }}\right.$, RN4220 indel , and Newman ${ }^{\text {indel }}$ ) with ectopic expression of $r p l V^{\text {indel }}$. Meanwhile, these strains transferred with the wild-type $r p l V$ gene were used as control (Supplementary Figure 2). We found that the survival rates of $S$. aureus strains with ectopic expression of $\mathrm{rpl}^{\text {indel }}$ in different concentration of erythromycin were significantly higher than control strains (Figure 3C). And erythromycin MICs in $8325-4^{\text {indel }}, \mathrm{RN} 4220^{\text {indel }}$, and Newman ${ }^{\text {indel }}$ were $8 \mu \mathrm{g} / \mathrm{mL}$ respectively (Table 2), which suggests that ectopic expression of $r p l V^{\text {tndel }}$ in susceptible strains induced resistance to erythromycin.

\section{$r p l V^{\text {indel }}$ contributes to specific resistance to macrolides in S. aureus}

Next, we asked whether the $r p l V^{\text {tndel }}$ gene could induce resistance to other macrolides, including azithromycin and clarithromycin. First, we also found the same results with erythromycin susceptibility test. The survival rates of $8325^{\mathrm{ER}+}$ strain in different concentration of azithromycin and clarithromycin were significantly

A

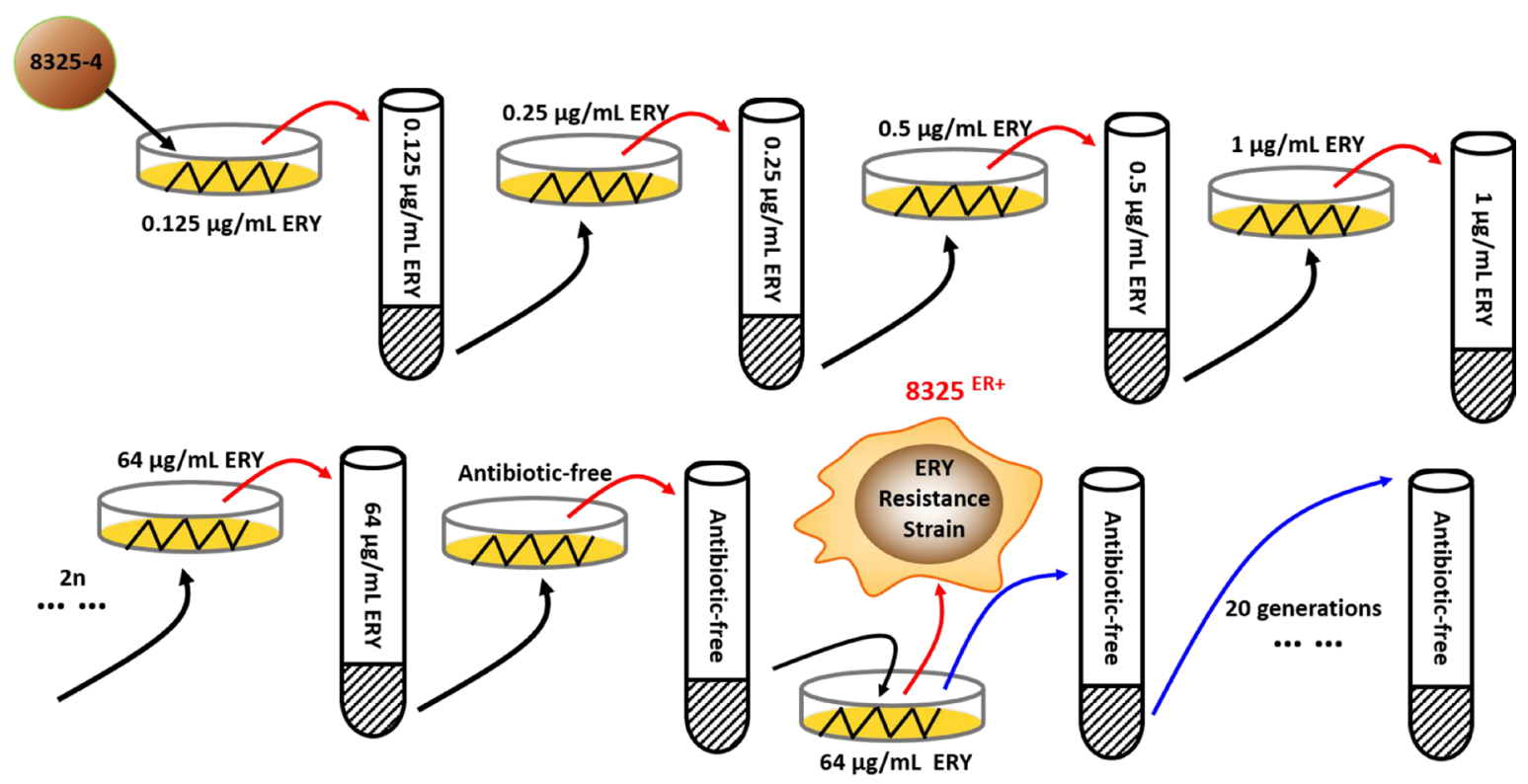

B

\section{Erythromycin}

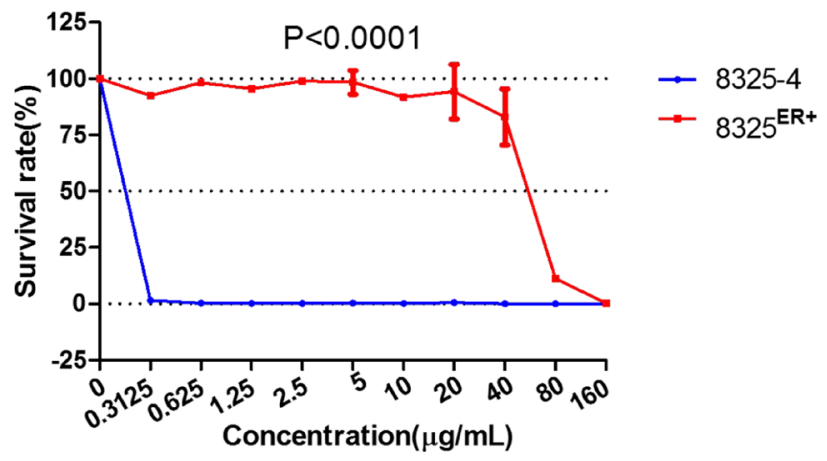

Figure 1: Erythromycin-resistant strain $\mathbf{8 3 2 5}^{\mathrm{ER}+}$. (A) Schematic diagram of stepwise screening for resistance to erythromycin (ERY) of wild-type S. aureus. 8325-4 was cultured and passaged in BHI medium supplemented with various concentrations of erythromycin (initially $0.125 \mu \mathrm{g} / \mathrm{mL}$, followed by two-fold increased until the concentration of erythromycin reached $64 \mu \mathrm{g} / \mathrm{mL}$ ). Each screening step included solid and liquid BHI medium for screening. Solid medium was used for picking an isolate of $S$. aureus at $37^{\circ} \mathrm{C}$ incubator for $12 \mathrm{~h}$, and liquid medium was used for enrichment of the isolate at $37^{\circ} \mathrm{C}$ with shaking at $220 \mathrm{rpm}$. When screening was completed, the erythromycin-resistant isolate was inoculated in BHI medium without antibiotics for 20 generations. (B) Survival rates of 8325-4 and $8325^{\mathrm{ER}+}$ in different concentration of erythromycin. The survival curve of wild-type $8325-4$ is shown in blue and the $8325^{\mathrm{ER}+}$ strain in red. Values are the means of triplicate wells; error bars indicate SD. 
higher than parent strain (Figure 4A). We then determined the MIC of azithromycin and clarithromycin in $8325^{\mathrm{ER}+}$ as $200 \mu \mathrm{g} / \mathrm{mL}$ and $100 \mu \mathrm{g} / \mathrm{mL}$, respectively (Table 2). In line with expectation, the ectopic expression of rpl tindel in susceptible strains also induced resistance to these two antibiotics (Figure 4B-4D, Table 2).

As the ribosomal protein L22 is essential in formation of the ribosomal polypeptide exit tunnel [22], we then determined whether $r p l V^{\text {indel }}$ was involved in resistance to antibiotics targeting the ribosome. It was revealed that neither $8325^{\mathrm{ER}+}$ nor susceptible strains with ectopic expression of rpl $V^{\text {indel }}$ were resistant to chloramphenicol and linezolid (Table 2), which target the $50 \mathrm{~S}$ ribosomal subunit. Similar results were also obtained in a drug susceptibility test of antibiotics that target the $30 \mathrm{~S}$ subunit or cell wall (Table 2). Consistent with the

A

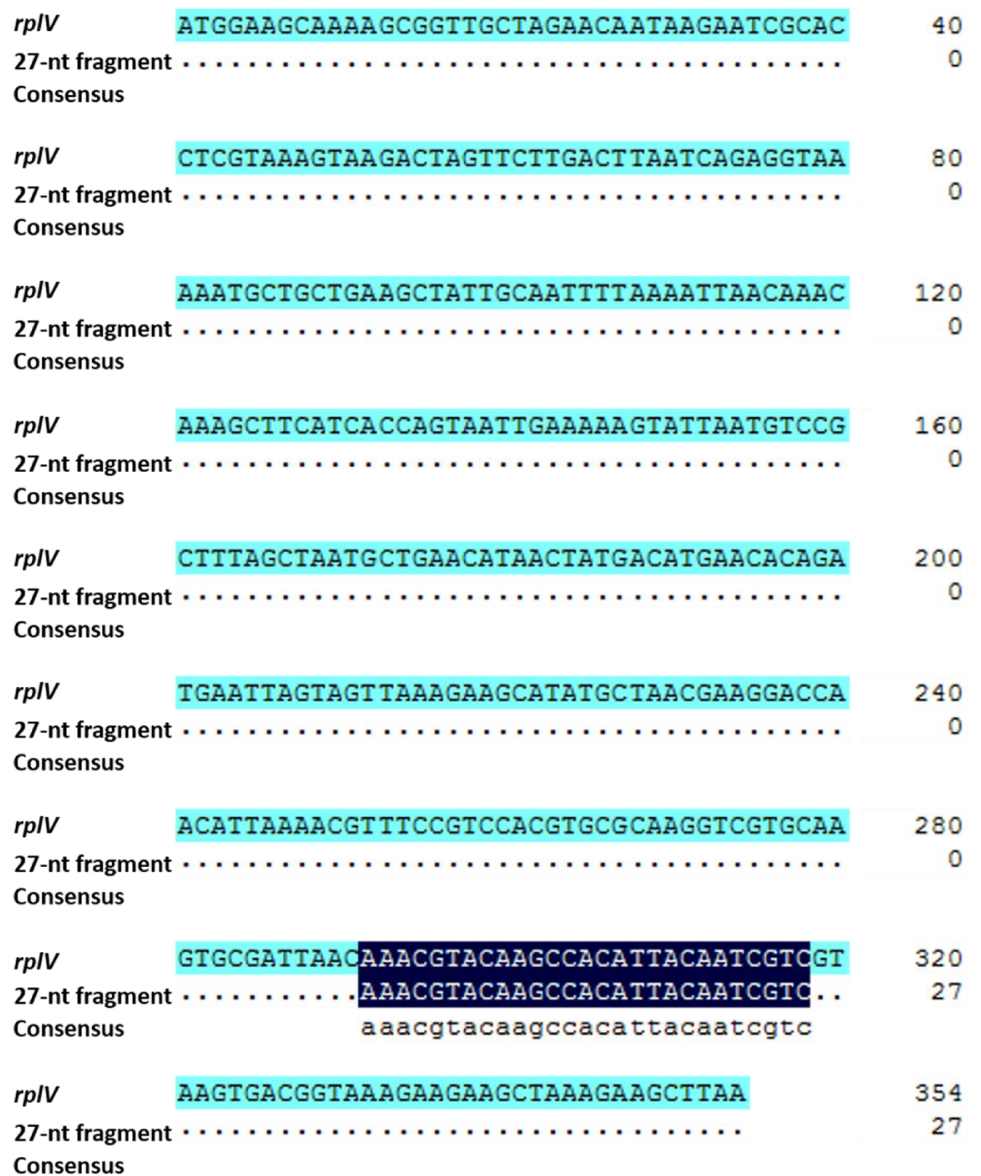

B
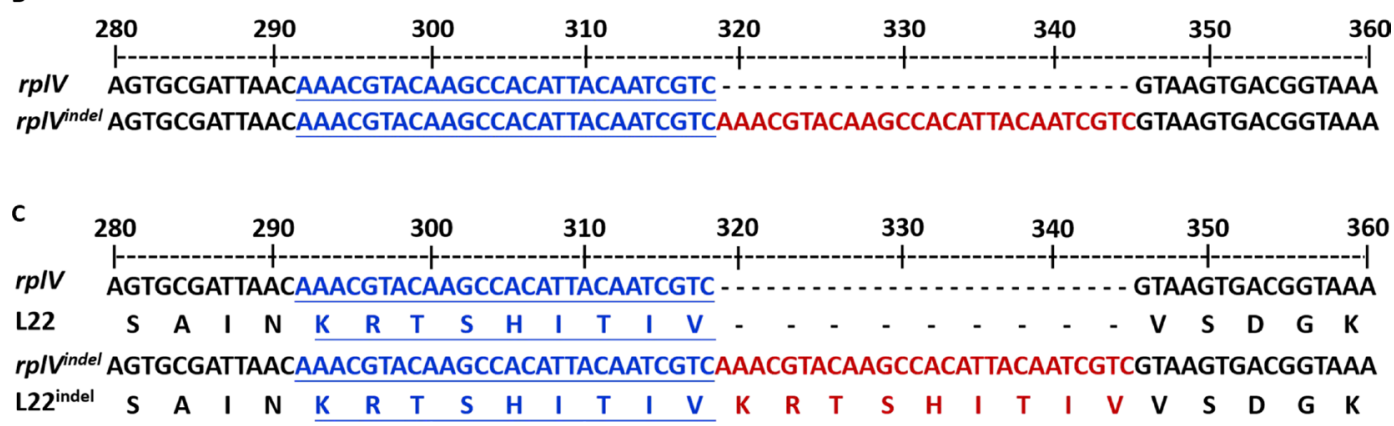

Figure 2: Insertion of a 27 nucleotide-repeat fragment in the rplV gene. (A) BLAST analysis of 27-nt fragment sequence. The top line shows the $r p l V$ gene, and the middle line shows 27-nt fragment sequences. BLAST results are shown for the total $r p l V$ nucleotides. (B) Nucleotides alignment of partial sequences of wild-type $r p l V$ and $r p l V^{\text {ndel }}$ to display the region 27-nt fragment insertion. The letters in blue and underlined on the middle line and bottom line are coincide with the inserted 27-nt fragment shown in red on the bottom line, and the 27-nt fragment is exactly adjacent to the region 292-318 of rplV. (C) Protein alignment of partial sequences of wild-type L22 and L22 $2^{\text {indel }}$ to display the inserted 27-nt fragment that led to a 9-amino acid insertion without frame-shifting mutation. The letters in blue and underlined are coincide with the inserted fragment shown in red on the line. 
Table 1: Comparison of whole-genome sequence of $8325^{\mathrm{ER}+}$ with $8325-4$

\begin{tabular}{|c|c|c|c|c|c|}
\hline $\begin{array}{l}\text { Type of } \\
\text { mutation }\end{array}$ & Nucleotide & Amino acid & Locus tag & Product & $\begin{array}{c}\text { Position in } \\
\text { chromosome }\end{array}$ \\
\hline \multirow{9}{*}{$\begin{array}{l}\text { Point } \\
\text { mutation }\end{array}$} & $\mathrm{T}$ to $\mathrm{A}$ & - & - & Noncoding & $\begin{array}{c}75324 \text { of } \\
\text { CP000253.1 }\end{array}$ \\
\hline & T $102 \mathrm{G}$ & G $34 \mathrm{G}$ & SAOUHSC_01078 & $\begin{array}{l}\text { ribosomal protein } \\
\text { L32 }\end{array}$ & $\begin{array}{l}1042000 \text { of } \\
\text { CP000253.1 }\end{array}$ \\
\hline & C $1988 \mathrm{~T}$ & S $663 \mathrm{~L}$ & SAOUHSC_01583 & $\begin{array}{l}\text { conserved } \\
\text { hypothetical } \\
\text { phage protein }\end{array}$ & $\begin{array}{l}1508580 \text { of } \\
\text { CP000253.1 }\end{array}$ \\
\hline & C $530 \mathrm{G}$ & A $177 \mathrm{G}$ & SAOUHSC_01748 & $\begin{array}{l}\text { queuine tRNA- } \\
\text { ribosyltransferase }\end{array}$ & $\begin{array}{l}1653225 \text { of } \\
\text { CP000253.1 }\end{array}$ \\
\hline & A $184 \mathrm{G}$ & R $62 \mathrm{G}$ & SAOUHSC_02163 & $\begin{array}{l}\text { conserved } \\
\text { hypothetical } \\
\text { phage protein }\end{array}$ & $\begin{array}{l}2031924 \text { of } \\
\text { CP000253.1 }\end{array}$ \\
\hline & $\mathrm{G}$ to $\mathrm{A}$ & - & SAOUHSC_R0005 & $\begin{array}{c}\text { 16S ribosomal } \\
\text { RNA }\end{array}$ & $\begin{array}{c}2243146 \text { of } \\
\text { CP000253.1 }\end{array}$ \\
\hline & A $208 \mathrm{C}$ & T $70 \mathrm{P}$ & SAOUHSC_02511 & $\begin{array}{l}\text { ribosomal protein } \\
\text { L4 }\end{array}$ & $\begin{array}{l}2316907 \text { of } \\
\text { CP000253.1 }\end{array}$ \\
\hline & G $206 \mathrm{C}$ & G $69 \mathrm{~A}$ & SAOUHSC_02511 & $\begin{array}{l}\text { ribosomal protein } \\
\text { L4 }\end{array}$ & $\begin{array}{l}2316909 \text { of } \\
\text { CP000253.1 }\end{array}$ \\
\hline & A to $\mathrm{G}$ & - & - & Noncoding & $\begin{array}{l}2350008 \text { of } \\
\text { CP000253.1 }\end{array}$ \\
\hline $\begin{array}{l}\text { Fragment } \\
\text { insertion }\end{array}$ & $\begin{array}{c}\text { C } 291 \text { or } 318 \text { to } \\
\text { CAAACGTACAAGCCA } \\
\text { CATTACAATCGTC }\end{array}$ & KRTSHITIV & SAOUHSC_02507 & $\begin{array}{l}\text { ribosomal protein } \\
\text { L22 }\end{array}$ & $\begin{array}{l}2314658 \text { of } \\
\text { CP000253.1 }\end{array}$ \\
\hline
\end{tabular}

MICs of non-macrolide antibiotics of $8325^{\mathrm{ER}+}$ strain or susceptible strains with ectopic expression of $r p l l^{\text {tndel }}$, there were no significant differences observed among the survival rates of those $S$. aureus strains comparing with their control strains (Supplementary Figures 3A-3B, $4 \mathrm{~A}-4 \mathrm{C})$.

\section{DISCUSSION}

Macrolides are usually used in clinical therapy for skin infections caused by $S$. aureus. Several mechanisms involved in $S$. aureus resistance to macrolides have been revealed. In this study, we revealed that a $27-n t$ insertion in the $r p l V$ gene induced a specific resistance to macrolides.

The $8325^{\mathrm{ER}+}$ resistance to macrolides was not due to the occurrence of identified erythromycin-resistant genes $\left(\right.$ ermA/ermB/ermC/mphC/msrA) but the rpl $V^{\text {tndel }}$ gene. Interestingly, the $27-n t$ insertion sequence is a repeat sequence of the $r p l V$ gene, but it did not induce frameshifting mutation. Sequence analysis showed that this fragment might be inserted behind $291 \mathrm{C}$ or $318 \mathrm{C}$. The ectopic expression of the $\mathrm{rpl}^{\text {thdel }}$ gene in several susceptible strains specifically conferred resistance to macrolide antibiotics. As shown in Table 2, the MIC of macrolides was higher in $8325^{\mathrm{ER}+}$ than in $8325^{\text {indel }}$. We think this may be majorly due to the coexistence of $r p l V$ and $r p l V^{\text {tndel }}$. The ribosome consisting of ribosomal protein L22 (rplV) is still sensitive to macrolides. Mutations in other genes may also contribute the resistance to macrolides in $8325^{\mathrm{ER}+}$. These assumptions will be investigated in the future.

In 1967, bacterial resistance to macrolides, caused by mutations in ribosomal protein, was reported [25]. In E. coli, it has been found that the deletion of $\mathrm{M}^{82} \mathrm{~K}^{83} \mathrm{R}^{84}$ increases expression of the AcrAB-TolC efflux system and results in resistance to macrolides $[21,26]$. Here, we reveal that a 27-nt insertion in the rplV gene confers specific resistance to macrolides in $S$. aureus. However, the level of $m s r A$, a well-identified gene of the efflux system involved in resistance to macrolides in staphylococci [17, 18], was not altered in $8325^{\mathrm{ER}+}$ compared with that of $8325-4$. The resistance to macrolides induced by $r p l V^{\text {tndel }}$ may be due to the conformational changes of L22 protein induced by the 27-nt insertion, which will be investigated in the future.

Ribosome protein L4 forms part of the lining of the peptide exit tunnel with L22. Mutations in ribosome protein L4 also induce macrolides resistance in a variety of pathogenic and non-pathogenic bacteria [21, 27-29]. There are two amino acids mutations (G69A, T70P) identified in the $\mathrm{L} 4$ protein from $8325^{\mathrm{ER}+}$, which may also contribute to the macrolides resistance. Although the ectopic expression of the $r p l V^{\text {tndel }}$ gene in several susceptible strains specifically conferred resistance to macrolide antibiotics, combination with the mutant L4 protein may further elevate the resistance. 
In this study, we tried to detect $r p l V^{\text {nndel }}$ in 84 clinical $S$. aureus isolates resistant to macrolides. Most of these strains harbor erm $A / B / C$ genes (Supplementary Table 1). There was no strain identified that contained the $r p l V^{\text {indel }}$ genes (data not shown). These results indicate that the occurrence of $r p l l^{\text {tndel }}$ in clinical isolates is rare compared with that of erm genes.

In conclusion, our findings present a $27-n t$ insertion in $r p l V$ that induces the specific resistance to macrolides in $S$. aureus.

\section{MATERIALS AND METHODS}

\section{Bacterial strains, plasmids, and growth conditions}

The strains and plasmids used in this study are listed in Supplementary Table 2. 84 Clinical macrolidesresistant $S$. aureus obtained from Department of Clinical Laboratory, Peking University People's Hospital. Distributions of the 84 clinical samples of $S$. aureus by origin of recovery were 22 strains from blood (26.2\%), 11 strains from pus $(13.1 \%), 14$ strains from secretions $(16.7 \%), 27$ strains from sputum $(32.1 \%), 9$ strains from wound $(10.7 \%)$ and one strain from abdominal fluid $(1.2 \%)$. Strains were cultured using brain heart infusion (BHI) medium (BD) at $37^{\circ} \mathrm{C}$ for $12 \mathrm{~h}$ with shaking at $220 \mathrm{rpm}$. Clinical isolates and wild-type strains including 8325-4, RN4220 and Newman were cultured in antibiotic-free BHI broth, while $8325^{\mathrm{ER}+}$ strain was cultured in BHI broth supplemented with $50 \mu \mathrm{g} / \mathrm{mL}$ erythromycin, those wild-type strains transformed with the shuttle plasmid pOS1 supplemented with $25 \mu \mathrm{g} /$ $\mathrm{mL}$ chloramphenicol, E. coli strain transformed with a cloning plasmid pMD-19T supplemented with $100 \mu \mathrm{g} /$ $\mathrm{mL}$ ampicillin.

\section{Erythromycin screen in vitro}

Schematic diagram of stepwise screening for resistance to erythromycin of wild-type $S$. aureus was showed in Figure 1A. 8325-4 was cultured and passaged

A

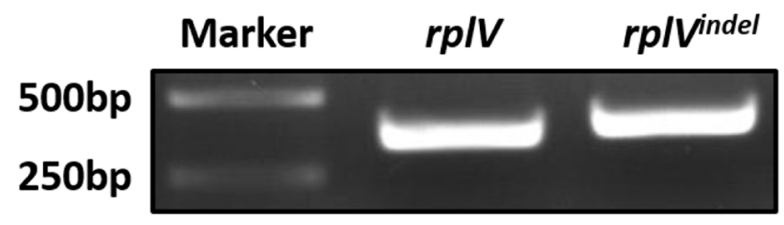

B

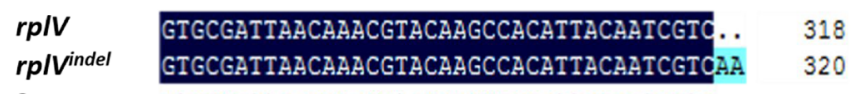

Consensus gtgcgattaacaacgtacaagccacattacaatcgtc

rplv $\quad \ldots \ldots \ldots \ldots \ldots \ldots \ldots$ GTAAGTGACGGTAAA 333

rp/vindel ACGTACAAGCCACATTACAATCGTdGTAAGTGACGGTAAA 360

Consensus

gtaagtgacggtaaa

rplV GAAGAAGCTAAAGAAGCTTAA 354

rplvindel GAAGAAGCTAAAGAAGTTAA 381

Consensus gaagaagctaaagaagcttaa

C

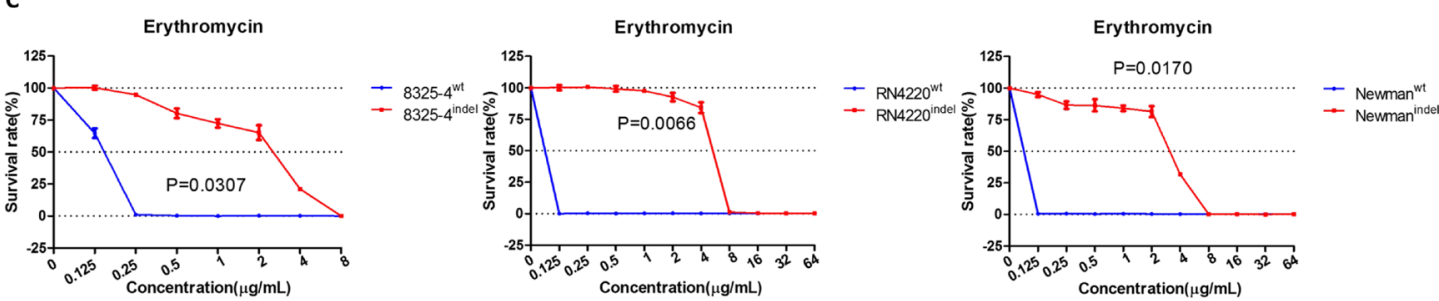

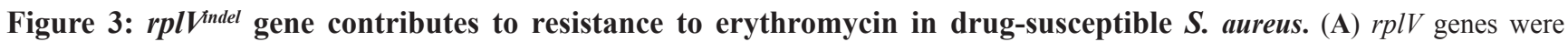
amplified by PCR from the genomes of 8325-4 and $8325^{\text {ER+ }}$, and PCR products were resolved on a $2 \%$ agarose gel and visualized by ultraviolet imaging. (B) The nucleotides were sequenced by Sangon Biotech, and BLAST analysis was performed using DNAMAN. The top line shows wild-type $r p l V$, and the middle line shows $r p l V^{\text {ndel }}$. BLAST results are shown for part of the total $r p l V$ nucleotides. $(\mathbf{C})$ Survival rates of recombinant 8325-4, RN4220, and Newman cells in different concentration of erythromycin. Drug-susceptible $S$. aureus cells transformed with the $r p l V^{\text {ndel }}$ gene exhibit decreased sensitivity to erythromycin. The survival curve of cells harboring wild-type $r p l V$ gene is shown in blue and the $r p l V^{\text {ndel }}$ gene is shown in red. Values are the means of triplicate wells; error bars indicate SD. 
Table 2: Antimicrobial agent susceptibility of Staphylococcus strains

\begin{tabular}{|c|c|c|c|c|c|c|c|c|}
\hline \multirow{3}{*}{$\begin{array}{l}\text { Antimicrobial } \\
\text { Agents }\end{array}$} & \multicolumn{8}{|c|}{$\mathrm{MIC}(\mu \mathrm{g} / \mathrm{mL})^{*}$} \\
\hline & \multicolumn{4}{|c|}{$8325-4$} & \multicolumn{2}{|c|}{ RN4220 } & \multicolumn{2}{|c|}{ Newman } \\
\hline & $8325-4$ & $8325^{\text {ER+ }}$ & $8325-4^{\text {wt }}$ & $8325-4^{\text {indel }}$ & RN4220 & RN4220 $^{\text {indel }}$ & Newman ${ }^{\text {wt }}$ & Newman $^{\text {indel }}$ \\
\hline Erythromycin & $0.3125^{\mathrm{S}}$ & $160^{\mathrm{R}}$ & $0.25^{\mathrm{S}}$ & $8^{R}$ & $0.125^{\mathrm{S}}$ & $8^{\mathrm{R}}$ & $0.125^{\mathrm{S}}$ & $8^{\mathrm{R}}$ \\
\hline Azithromycin & $0.78125^{\mathrm{s}}$ & $200^{\mathrm{R}}$ & $0.5^{\mathrm{s}}$ & $16^{\mathrm{R}}$ & $0.5^{\mathrm{s}}$ & $32^{\mathrm{R}}$ & $0.5^{\mathrm{s}}$ & $32^{\mathrm{R}}$ \\
\hline Clarithromycin & $0.1953125^{\mathrm{s}}$ & $100^{\mathrm{R}}$ & $0.125^{\mathrm{s}}$ & $8^{\mathrm{R}}$ & $0.125^{\mathrm{s}}$ & $8^{\mathrm{R}}$ & $0.125^{\mathrm{s}}$ & $8^{\mathrm{R}}$ \\
\hline Chloramphenicol & 5 & 5 & - & - & - & - & - & - \\
\hline Linezolid & 1.25 & 1.25 & 0.625 & 0.625 & 1 & 1 & 1 & 1 \\
\hline Tobramycin & 1.25 & 1.25 & 2.5 & 2.5 & 2 & 2 & 2 & 2 \\
\hline Kanamycin & 5 & 5 & 5 & 5 & 8 & 8 & 8 & 8 \\
\hline Vancomycin & 1.25 & 1.25 & 1 & 1 & 1 & 1 & 2 & 2 \\
\hline
\end{tabular}

"The MICs of corresponding antibiotic shown with letter "R" represent "Resistant", those with letter "S" represent "Susceptible" according to CLSI criteria.

in BHI medium supplemented with various concentrations of erythromycin (initially $0.125 \mu \mathrm{g} / \mathrm{mL}$, followed by twofold increased until the concentration of erythromycin reached $64 \mu \mathrm{g} / \mathrm{mL}$ ). Each screening step included solid and liquid BHI medium for screening. Solid medium was used for picking an isolate of $S$. aureus at $37^{\circ} \mathrm{C}$ incubator for $12 \mathrm{~h}$, and liquid medium was used for enrichment of the isolate at $37^{\circ} \mathrm{C}$ with shaking at $220 \mathrm{rpm}$. When screening was completed, the erythromycin-resistant isolate was inoculated in BHI medium without antibiotics for 20 generations.

\section{Measurement of bacterial growth curve}

Bacteria were incubated in BHI broth at $37^{\circ} \mathrm{C}$ with shaking at $220 \mathrm{rpm}$ overnight. The concentration of bacteria was adjusted to $1 \times 10^{7} \mathrm{cfu} / \mathrm{mL}$, then $1: 100$ inoculated in BHI broth without antibiotics at $37^{\circ} \mathrm{C}$ with shaking at $220 \mathrm{rpm}$ for 12 hours. Growth curves of bacteria were constructed by measuring of the cell density at $\mathrm{A} 600 \mathrm{~nm}$ at one-hour intervals for 12 hours.

\section{Antibiotic susceptibility assay}

Antibiotics were purchased from Selleck. Susceptibility to antibiotics was tested by using broth microdilution method according to the Clinical and Laboratory Standards Institute (CLSI) [24]. Briefly, antibiotics were prepared by serial two-fold dilutions in BHI broth, then various concentration of antibiotics were made in triplicate in 96-well culture dishes containing $1 \times 10^{5} \mathrm{cfu} /$ well bacteria and incubated for $18-24 \mathrm{~h}$ at $37^{\circ} \mathrm{C}$. Control wells were free of antibiotic. Bacteria growth was determined by reading the optical density (OD) at $630 \mathrm{~nm}$. The survival rates of bacteria were calculated by the rates of OD $630 \mathrm{~nm}$ measurement at each concentration of antibiotic versus control wells. The MIC was determined to be the dose of antibiotic that inhibited bacteria growth by $>95 \%$.

\section{RNA isolation and RT-PCR}

For detecting erythromycin resistance genes in $S$. aureus. Total bacterial RNA was extracted from $S$. aureus, which were grown with shaking at $37^{\circ} \mathrm{C}$ using Trizol (Invitrogen) as previously described [30]. Briefly, DNase digestion of $80 \mu \mathrm{L}$ of total RNA was performed with $10 \mathrm{U}$ of RNase-free DNase I (Promega) and $10 \mu \mathrm{L}$ of the $10 \times$ reaction buffers in a total reaction volume of $100 \mu \mathrm{L}$ for $30 \mathrm{~min}$ at $37^{\circ} \mathrm{C}$. For cDNA synthesis, $6 \mu \mathrm{L}$ total RNA $\left(\approx 250 \mathrm{ng}\right.$ ) was incubated at $65^{\circ} \mathrm{C}$ for $5 \mathrm{~min}$, then add $2 \mu \mathrm{L}$ of $4 \times$ DNA remove buffer and incubate at $37^{\circ} \mathrm{C}$ for $5 \mathrm{~min}$, finally add $2 \mu \mathrm{L}$ of $5 \times$ RT Master MixII (TOYOBO) and incubate at $37^{\circ} \mathrm{C}$ for $15 \mathrm{~min}, 50^{\circ} \mathrm{C}$ for $5 \mathrm{~min}, 98^{\circ} \mathrm{C}$ for $5 \mathrm{~min}$.

\section{Detection of macrolides-resistance genes}

Macrolides resistance genes ermA, ermB, erm $C$, $m s r A$ and $m p h C$ were examined in the erythromycinsensitive strain 8325-4 and the erythromycin-resistant strain $8325^{\mathrm{ER}+}$ with primers listed in Supplementary Table 3. The PCR reaction mixture contained $2.5 \mu \mathrm{L}$ of $10 \times$ PCR reaction buffer, $0.25 \mu \mathrm{L}$ enzyme, $0.5 \mu \mathrm{L}$ dNTP mix, $0.3 \mathrm{mM}$ of gene-specific forward and reverse primers, and $2 \mu \mathrm{L}$ of template, made up to a final volume of $25 \mu \mathrm{L}$ with distilled water. Cycling parameters were set as follows: initial activation step at $95^{\circ} \mathrm{C}$ for $5 \mathrm{~min}$, denaturation at $95^{\circ}$ $\mathrm{C}$ for $30 \mathrm{~s}$, annealing at $55^{\circ} \mathrm{C}$ for $30 \mathrm{~s}$, and extension at $72^{\circ} \mathrm{C}$ for $30 \mathrm{~s}$. gyrB was used as the endogenous reference gene. The PCR products were resolved in $2 \%$ agarose gel and visualized by ultraviolet imaging.

\section{Whole-genome sequencing of $S$. aureus}

Bacteria were grown in BHI broth at $37^{\circ} \mathrm{C}$ for $12 \mathrm{~h}$ with shaking at $220 \mathrm{rpm}$ and harvested by centrifuge at $12000 \mathrm{rpm}$ for $1 \mathrm{~min}$. Genomic DNA was extracted by using EasyPure ${ }^{\circledR}$ Bacteria Genomic DNA Kit (TransGen 
Biotech) according to manufacturer's instruction. Sequencing with constructed shotgun libraries of 8325 4 and $8325^{\mathrm{ER}+}$ was performed by Illumina Hiseq 2000. Fragmentation, library construction, and sequencing were carried out by oebiotech company.

A

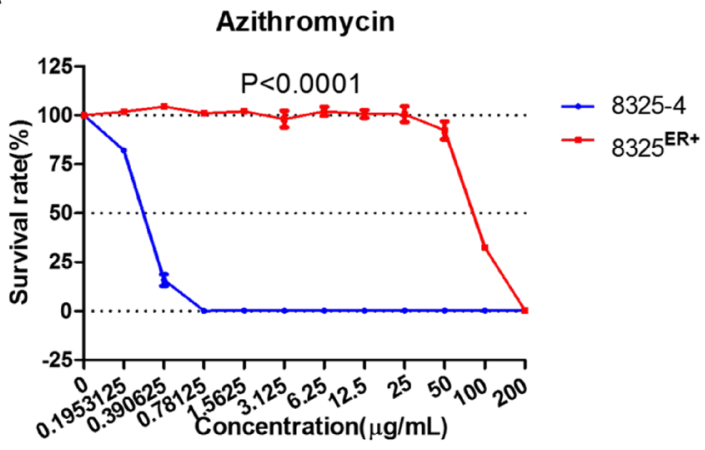

B

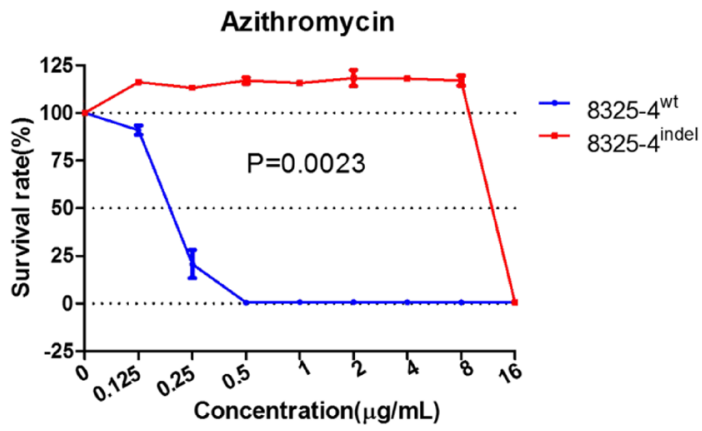

C

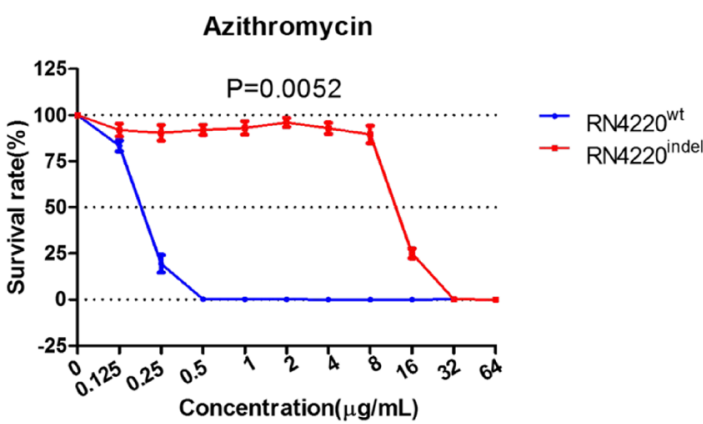

D

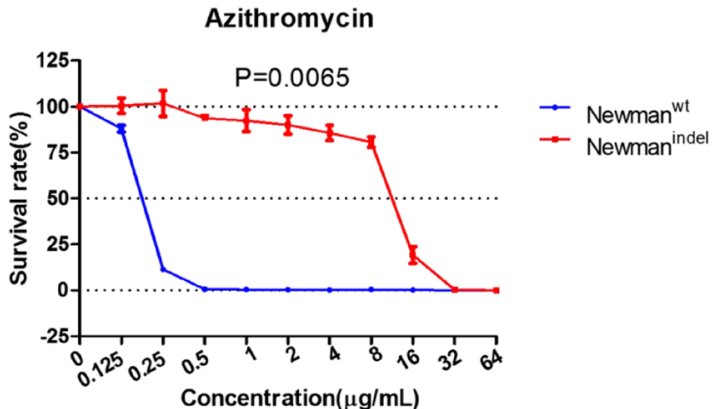

Analysis of the $r p l V$ gene in clinical isolates

For detecting 27-nt fragment insertion in rplV gene in clinical macrolides resistant $S$. aureus isolates, the $r p l V^{\text {indel }}$ gene was detected by PCR amplification. Primers

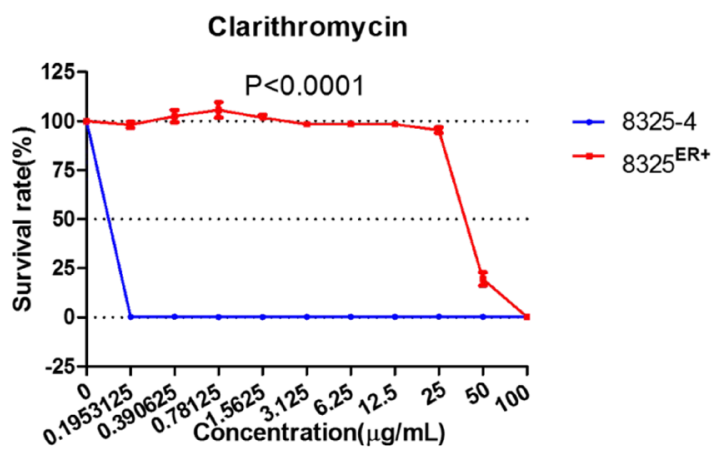

Clarithromycin
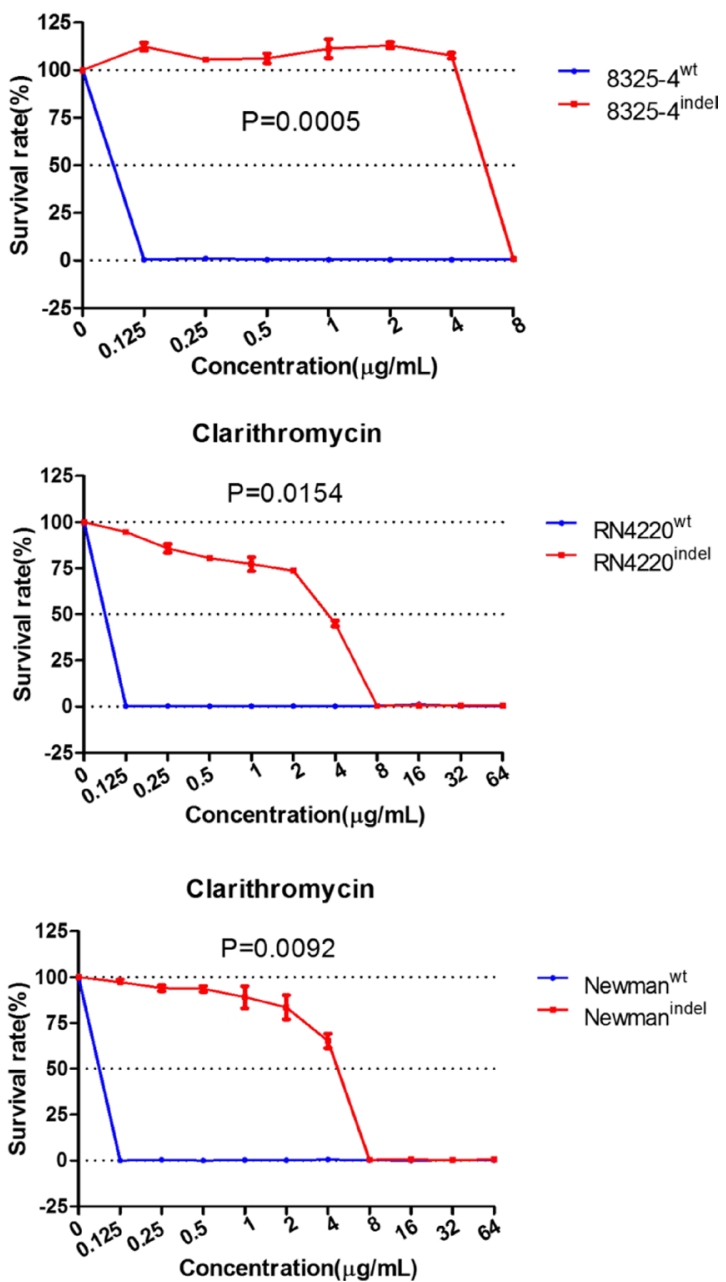

Figure 4: $\mathbf{r p l} \mathbf{V}^{\text {indel }}$ gene contributes to resistance to macrolides in drug-susceptible $\boldsymbol{S}$. aureus. (A) Survival rates of 8325 and $8325^{\text {ER+ }}$ in different concentration of azithromycin (left) and clarithromycin (right). (B) Survival rates of wild-type $S$. aureus $8325-4$ cell transformed with the $r p l V^{\text {indel }}$ gene exhibit decreased sensitivity to azithromycin (left) and clarithromycin (right). (C) Survival rates of drugsusceptible RN4220 cell transformed with the $r p l V^{\text {ndel }}$ gene exhibit decreased sensitivity to azithromycin (left) and clarithromycin (right). (D) Survival rates of drug-susceptible Newman cell transformed with the $r p l V^{\text {ndel }}$ gene exhibit decreased sensitivity to azithromycin (left) and clarithromycin (right). The survival curve of cells harboring wild-type $r p l V$ gene is shown in blue and the $r p l l^{\text {nndel }}$ gene is shown in red. Values are the means of triplicate wells; error bars indicate SD. 
used for the $r p l V$ gene were $r p l V$-F and $r p l V$-R listed in Supplementary Table 3. Clinical isolates were grown on blood agar plates and incubated overnight at $37^{\circ} \mathrm{C}$, bacteria DNA was prepared by suspending a fresh colony in $400 \mu \mathrm{L}$ of sterile distilled water and heating at $100^{\circ} \mathrm{C}$ for $10 \mathrm{~min}$ and then centrifuged at $12000 \mathrm{rpm}$ for $5 \mathrm{~min}$. PCR amplification was carried out under the following conditions: $95^{\circ} \mathrm{C}$ for $5 \mathrm{~min}$, followed by 34 cycles of $95^{\circ} \mathrm{C}$ for $30 \mathrm{~s}, 56^{\circ} \mathrm{C}$ for $30 \mathrm{~s}, 72^{\circ} \mathrm{C}$ for $30 \mathrm{~s}$, and $72^{\circ} \mathrm{C}$ for $5 \mathrm{~min}$. PCR products were resolved on a $2 \%$ agarose gel and visualized by ultraviolet imaging. The nucleotides were sequenced by Sangon Biotech, and BLAST analysis was performed using DNAMAN.

\section{Ectopic expression of $r p l V^{\text {tndel }}$ in $S$. aureus strains}

rplV genes were amplified by PCR from the genomes of wild-type $S$. aureus $8325-4$ and the erythromycin-resistant strain $8325^{\mathrm{ER}+}$ with primers $r p l V$ F-EcoRI and rplV-R-BamHI (Supplementary Table 3). The PCR products were ligated into pMD-19T vector, the recombinant plasmids were transformed into DH5a. The recombinant pMD-19T plasmid was eliminated by cutting the plasmid with the EcoRI and BamHI restriction enzymes, then digested fragments were ligated into EcoRI and BamHI-digested pOS1 vector. The recombinant plasmids were transformed into $\mathrm{DH} 5 \mathrm{a}$, then electrotransformation into recipient strains $S$. aureus RN4220. The plasmid was isolated from RN4220, then electrotransformation into $S$. aureus $8325-4$ and Newman.

\section{Statistical analyses}

Statistical tests were performed using GraphPad Prism v.5.0 (GraphPad Software Inc., San Diego, CA, United States). The Differences between survival curves were evaluated for statistical significance using the unpaired $t$ test. All $P$-values of $\leq 0.05$ was considered significant.

\section{Abbreviations}

rplV: ribosomal protein L22; rplV $V^{\text {indel }}$ : 27-nucleotide repeat sequence insertion in rplV gene; rRNA: ribosomal RNA; erm: erythromycin resistance methyltransferase; ABC: ATP-binding cassette; msrA: macrolide-streptogramins resistance $\mathrm{A} ;$ mphC: macrolide phosphotransferase C; RT-PCR: reverse transcriptionpolymerase chain reaction; ERY: erythromycin; MIC: minimal inhibitory concentration; CLSI: Clinical and Laboratory Standards Institute.

\section{Author contributions}

G.Y. study concept and design, obtained funding; D.H. acquisition of data, analysis and interpretation of data; D.H. and Y.L. drafting of the manuscript; Y.L., J.L.,
C.L., Y.G., J.F. and H.L. administrative, technical, and material support; G.Y. and H.L. study supervision.

\section{ACKNOWLEDGMENTS}

We thank Dr. Hui Wang of Peking university people's hospital for providing clinical macrolidesresistant $S$. aureus.

\section{CONFLICTS OF INTEREST}

The authors declare no conflicts of interest.

\section{FUNDING}

This work was supported by grant from National Natural Science Foundation of China (http://www.nsfc. gov.cn) [31370170].

\section{REFERENCES}

1. Day NPJ, Moore CE, Enright MC, Berendt AR, Smith JM, Murphy MF, Peacock SJ, Spratt BG, Feil EJ. A link between virulence and ecological abundance in natural populations of Staphylococcus aureus (Retraction of vol 292, 114, 2001). Science. 2002; 295:971-971.

2. Archer GL. Staphylococcus aureus: a well-armed pathogen. Clin Infect Dis. 1998; 26:1179-1181.

3. Beceiro A, Tomas M, Bou G. Antimicrobial resistance and virulence: a successful or deleterious association in the bacterial world? Clin Microbiol Rev. 2013; 26:185-230.

4. Klevens RM, Morrison MA, Nadle J, Petit S, Gershman K, Ray S, Harrison LH, Lynfield R, Dumyati G, Townes JM, Craig AS, Zell ER, Fosheim GE, et al. Invasive methicillinresistant Staphylococcus aureus infections in the United States. JAMA. 2007; 298:1763-1771.

5. Boucher HW, Sakoulas G. Perspectives on Daptomycin resistance, with emphasis on resistance in Staphylococcus aureus. Clin Infect Dis. 2007; 45:601-608.

6. Sanchez Garcia M, De la Torre MA, Morales G, Pelaez B, Tolon MJ, Domingo S, Candel FJ, Andrade R, Arribi A, Garcia N, Martinez Sagasti F, Fereres J, Picazo J. Clinical outbreak of linezolid-resistant Staphylococcus aureus in an intensive care unit. JAMA. 2010; 303:2260-2264.

7. Brisson-Noel A, Trieu-Cuot P, Courvalin P. Mechanism of action of spiramycin and other macrolides. J Antimicrob Chemother. 1988; 22:13-23.

8. Walsh C. Molecular mechanisms that confer antibacterial drug resistance. Nature. 2000; 406:775-781.

9. Watanabe Y, Morimoto S, Adachi T, Kashimura M, Asaka T. Chemical modification of erythromycins. IX. Selective methylation at the C-6 hydroxyl group of erythromycin A oxime derivatives and preparation of clarithromycin. J Antibiot (Tokyo). 1993; 46:647-660. 
10. Klein JO. History of macrolide use in pediatrics. Pediatr Infect Dis J. 1997; 16:427-431.

11. Peterson JH, Woolhead CA, Bernstein HD. The conformation of a nascent polypeptide inside the ribosome tunnel affects protein targeting and protein folding. Mol Microbiol. 2010; 78:203-217.

12. Menninger JR, Otto DP. Erythromycin, carbomycin, and spiramycin inhibit protein synthesis by stimulating the dissociation of peptidyl-tRNA from ribosomes. Antimicrob Agents Chemother. 1982; 21:811-818.

13. Gaynor M, Mankin AS. Macrolide antibiotics: binding site, mechanism of action, resistance. Curr Top Med Chem. 2003; 3:949-961.

14. Jenssen WD, Thakker-Varia S, Dubin DT, Weinstein MP. Prevalence of macrolides-lincosamides-streptogramin $\mathrm{B}$ resistance and erm gene classes among clinical strains of staphylococci and streptococci. Antimicrob Agents Chemother. 1987; 31:883-888.

15. Weisblum B. Erythromycin resistance by ribosome modification. Antimicrob Agents Chemother. 1995; 39:577-585.

16. Oldenburg M, Kruger A, Ferstl R, Kaufmann A, Nees G, Sigmund A, Bathke B, Lauterbach H, Suter M, Dreher S, Koedel U, Akira S, Kawai T, et al. TLR13 recognizes bacterial $23 \mathrm{~S}$ rRNA devoid of erythromycin resistanceforming modification. Science. 2012; 337:1111-1115.

17. Reynolds E, Ross JI, Cove JH. Msr(A) and related macrolide/streptogramin resistance determinants: incomplete transporters? Int J Antimicrob Agents. 2003; 22:228-236.

18. Otto M, Gotz F. ABC transporters of staphylococci. Res Microbiol. 2001; 152:351-356.

19. Wright GD. Bacterial resistance to antibiotics: enzymatic degradation and modification. Adv Drug Deliv Rev. 2005; 57:1451-1470.

20. Matsuoka M, Inoue M, Endo Y, Nakajima Y. Characteristic expression of three genes, $\operatorname{msr}(\mathrm{A}), \mathrm{mph}(\mathrm{C})$ and $\operatorname{erm}(\mathrm{Y})$, that confer resistance to macrolide antibiotics on Staphylococcus aureus. FEMS Microbiol Lett. 2003; 220:287-293.

21. Chittum HS, Champney WS. Ribosomal protein gene sequence changes in erythromycin-resistant mutants of Escherichia coli. J Bacteriol. 1994; 176:6192-6198.
22. Gregory ST, Dahlberg AE. Erythromycin resistance mutations in ribosomal proteins L22 and L4 perturb the higher order structure of $23 \mathrm{~S}$ ribosomal RNA. J Mol Biol. 1999; 289:827-834.

23. Malbruny B, Canu A, Bozdogan B, Fantin B, Zarrouk V, Dutka-Malen S, Feger C, Leclercq R. Resistance to quinupristin-dalfopristin due to mutation of L22 ribosomal protein in Staphylococcus aureus. Antimicrob Agents Chemother. 2002; 46:2200-2207.

24. CLSI. Methods for dilution antimicrobial susceptibility tests for bacteria that grow aerobically, 9th ed. Approved standard. Clinical and Laboratory Standards Institute, Wayne, PA. 2012.

25. Wittmann HG, Stoffler G, Apirion D, Rosen L, Tanaka K, Tamaki M, Takata R, Dekio S, Otaka E. Biochemical and genetic studies on two different types of erythromycin resistant mutants of Escherichia coli with altered ribosomal proteins. Mol Gen Genet. 1973; 127:175-189.

26. Moore SD, Sauer RT. Revisiting the mechanism of macrolide-antibiotic resistance mediated by ribosomal protein L22. Proc Natl Acad Sci U S A. 2008; 105:18261-18266.

27. Hao H, Yuan Z, Shen Z, Han J, Sahin O, Liu P, Zhang Q. Mutational and transcriptomic changes involved in the development of macrolide resistance in Campylobacter jejuni. Antimicrob Agents Chemother. 2013; 57:1369-1378.

28. Descours G, Ginevra C, Jacotin N, Forey F, Chastang J, Kay E, Etienne J, Lina G, Doublet P, Jarraud S. Ribosomal Mutations Conferring Macrolide Resistance in Legionella pneumophila. Antimicrob Agents Chemother. 2017; 61:e02188-16.

29. Prunier AL, Trong HN, Tande D, Segond C, Leclercq R. Mutation of L4 ribosomal protein conferring unusual macrolide resistance in two independent clinical isolates of Staphylococcus aureus. Microb Drug Resist. 2005; 11:18-20.

30. Yan J, Han D, Liu C, Gao Y, Li D, Liu Y, Yang G. Staphylococcus aureus VraX specifically inhibits the classical pathway of complement by binding to C1q. Mol Immunol. 2017; 88:38-44. 